\title{
Mulheres, realidade social e desafios emancipatórios
}

\author{
Mulher, Estado e Revolução: \\ política familiar e vida social \\ soviéticas, 1917-1936.
}

GOLDMAN, Wendy Z.
São Paulo: Boitempo, 2014, 399p.

Pouco mais de uma década após lançamento original nos Estados Unidos, o livro Mulher, Estado e Revolução: política familiar e vida social Soviéticas, 1917-1936, ganhou sua edição no Brasil, pela editora Boitempo, em março de 2014, por meio da tradução de Natália Angyalossi Alfonso. Nesta obra, a historiadora Wendy Goldman, Professora da Universidade Carnegie Mellon, em Pittsburgh (Pensilvânia, EUA), aborda, em oito detalhados e bem escritos capítulos, as profundas transformações sociais ocorridas na União Soviética nos primeiros anos da revolução de 1917, trazendo-nos valiosas contribuições e elucidações do pensamento bolchevique acerca do papel e o lugar das mulheres nas relações familiares daquele período.

A principal contribuição da autora neste sentido é articular meticulosamente as ideias dos teóricos marxistas e soviéticos apontando os traços inovadores e os limites de seus pensamentos ao que tange às reflexões acerca da emancipação da mulher. Já no primeiro capítulo somos convidados/as a um denso resgate de sete séculos de história do pensamento, sobretudo europeu, que nos leva da visão de 'amor livre' da Idade Média, ao Código do Casamento, da Família e da Tutela, lançado pelo Comitê Executivo Central do Soviete (VTsIK) - ponto de partida do livro -, em outubro de 1918.

Goldman nos elucida que o tema da emancipação feminina só foi tomado como questão a partir do século XIX, com as transfor- mações da estrutura produtiva e divisões do trabalho: neste embate, não só as reflexões dos intelectuais se contrastavam, como também o posicionamento dos próprios trabalhadores e trabalhadoras. Papel de destaque é dado às ponderações de Marx e Engels - em particular às ideias deste último em $A$ origem da família, da propriedade privada e do Estado - a partir das quais os teóricos soviéticos desenvolveram novas contribuições e movimentos feministas operários passaram a se organizar. Nesta movimentação de práxis, a autora destaca Alexandra Kollontai, August Bebel, Clara Zetkin e Elena Kabo. O fundamento do Código da Família de 1918 era 0 de transferir o trabalho doméstico para a esfera pública com o intuito de definhar o papel da família e emancipar a mulher. Mas, a autora mostra, página a página, no decorrer dos capítulos dois, três e quatro, como

[...] o desemprego, baixa qualificação, falto de serviços sociais e pobreza terrível eram fatores que mitigavam a independência feminina frente à unidade familiar. A ideia de 'união livre' teria consequências trágicas e imprevistas para as mulheres enquanto elas não pudessem sustentar a si próprias e a seus filhos. A lei nascida da tradição do socialismo libertário estava dolorosamente em contradição com a vida. ${ }^{1}$

De modo que a popularização da Lei, ao tornar acessível, dentre outras coisas, o divórcio, e prever pensão alimentícia, não foi suficientemente eficaz para gerar a transformação real da cultura que marcava o cotidiano de opressão das mulheres na União Soviética. O cenário de pobreza que se apresentava era marcado, ainda, pela prostituição e o abandono de crianças. Sendo assim, os "séculos de poder patriarcal estruturado, as mais básicas instituições sociais, econômicas e culturais, não poderiam ser facilmente desmontados somente pela lei" ${ }^{2}$ e pela imposição de um sistema de liberdades individuais, sobretudo às mulheres. 
Por conta disso, a primeira metade da década de 1920 fora marcada por um ferrenho debate em torno da reformulação do Código da Família de 1918. A grande motivação era eliminar as contradições entre a norma e a vida real, apresentando uma versão mais reduzida da Lei sem ambicionar diluir a importância do registro do casamento, objetivando garantir o direito à propriedade das mulheres, pensão alimentícia e a legalização da adoção. A autora chama a atenção, no entanto, para o fato de que os impulsos prós e contra o Código refletiam, na verdade, "a ausência de uma ideologia hegemônica monolíica que definisse o pape do direito na sociedade soviética, no início dos anos 1920".

Tanto é que, no sexto capítulo do livro, Goldman apresenta em detalhes 0 debate de ideias transcorrido entre quatro principais grupos sociais acerca do Novo Código da Família lançado em 1926, e efetivado a partir de 1927. Os camponeses, os protecionistas, os juristas progressistas e o grupo dos interesses da mulher divergiam, em particular, acerca do divórcio, do matrimônio de fato, do papel da lei e do Estado na proteção da mulher e do papel da própria família, respectivamente. Um dos aspectos mais marcantes e merecedor de destaque é que a maioria das mulheres "não eram feministas", portanto, "a emancipação das mulheres dos tradicionais papéis familiares era um assunto remoto para elas" que "procuravam preservar a família", ao passo que seu definhamento

[...] não representava uma reestruturação abstrata das relações de gênero, mas a possibilidade sempre presente de que fossem incapazes de alimentar seus filhos. A oposição das mulheres ao divórcio e à união livre era baseada em sua desesperada necessidade de total acesso ao salário do marido. ${ }^{4}$

A tentativa soviética de eliminar a instituição familiar e criar mecanismos para reverter a submissão das mulheres foi marcada por controvérsias do começo ao fim. Ainda que, no início da década de 1920 - mesmo que sem mecanismos contraceptivos eficazes que pudessem proteger a mulher das gravidezes indesejadas a União Soviética tenha se tornado "o primeiro país do mundo a dar a todas as mulheres a possibilidade legal e gratuita de interromper a gravidez", por meio de um decreto dos Comissários da Saúde e da Justiça que legalizou o aborto em novembro de 1920, Goldman desta-ca que "apesar da enorme liberdade que o decreto concedia às mulheres, nunca reconhe-ceu o aborto como um direito da mulher". ${ }^{5}$ Na prática, o acesso ao aborto favoreceu majorita-riamente as mulheres trabalhadoras urbanas. Como destaca a autora, "quase $85 \%$ das mulhe-res da Rússia viviam na zona rural, mas $85 \%$ dos abortos ocorriam nas cidades", 6 sendo que $86 \%$ "tinha[m] feito a transição para o mundo do tra-balho assalariado e estava estudando, trabalhan-do por um salário ou eram casadas com trabaIhadores"?

Este período, marcado pela massiva absorção das mulheres no mercado de trabalho industrial, gerou, em determinado momento, uma sensação otimista de que o intento Revolucionário de emancipação da mulher estava em vias de se tornar realidade, pois o Estado aumentou significativamente o investimento em creches, escolas e refeitórios comunitários. Acontece que "o novo entusiasmo pela libertação das mulheres teve vida curta", ${ }^{8}$ uma vez que seu ingresso no mercado de trabalho não emancipou sua dependência da família, posto que "a renda per capita não aumentou à medida que mais membros da família começaram a trabalhar, mas caiu $51 \%$, pois as mulheres ganham bem menos que os homens".

Tal realidade, somada ao retorno da criminalização do aborto, em meados dos anos 1930 causou significativo retrocesso no projeto emancipatório das mulheres. A incapacidade do Estado em ampliar as estruturas sociais não fez diminuir a pobreza, as crianças e mulheres (solteiras) sem-teto, nem tão pouco os delitos juvenis. Uma guinada ideológica fez com que os juristas voltassem atrás e não mais vissem este fenômeno a partir de causas sociais, mas, sim, passassem a interpretá-lo como consequências das transformações dos modos de vida; pelo ruir dos antigos padrões, sem o estabelecimento estável de uma nova forma de vida. A família e uma nova campanha pró-natalidade começaram a ser novamente fortalecidas a partir de 1936. Nas palavras de Goldman:

A lei de 1936 oferecia às mulheres uma barganha implícita: ela ampliava tanto a responsabilidade do Estado como a do homem pela família, mas em troca ela exigia que as mulheres assumissem o duplo fardo do trabalho e da maternidade. A ideia de que o Estado assumiria as funções da família foi abandonada. ${ }^{10}$

Apesar das riquíssimas descrições, cenas recontadas, debates teóricos recriados, dados inesgotáveis que demonstram uma pesquisa de alto rigor elaborada pela autora, Goldman apresenta as várias relações entre a controvérsia da Lei com a realidade socioeconômica e cultural soviética, mas estabelece poucos laços 
deste contexto com a política propriamente dita. Ela deixa uma breve 'conclusão' para relacionar a guinada ideológica aos novos conceitos de família, Estado e direito de Stalin, no entanto, não apresenta tão detalhadamente o embate interno destes novos choques de ideias.

Obviamente, isto não traz descrédito algum ao trabalho, que, além de apresentar contribuições altamente qualificadas aos estudos e reflexões acerca da emancipação das mulheres, até mesmo no contexto atual, abre uma gama de aspectos ainda inexplorados nesta seara.

\section{Notas}

1 Goldman, 2014, p. 186.

${ }^{2}$ Goldman, 2014, p. 228.

${ }^{3}$ Goldman, 2014, p. 247.

${ }^{4}$ Goldman, 2014, p. 293.

${ }^{5} 2014$, p. 305.

${ }^{6}$ Goldman, 2014, p. 315-316

${ }^{7}$ Idem.

${ }^{8}$ Idem, p. 366

${ }^{9}$ Goldman, 2014, p. 366

${ }^{10}$ Idem, p. 387.
Carla Simara Ayres Universidade Federal de Santa Catarina 